\title{
Management of Pediatric Unilateral Sensorineural Hearing Loss
}

\author{
Sung Wook Jeong and Lee-Suk Kim \\ Department of Otorhinolaryngology-Head and Neck Surgery, College of Medicine, Dong-A University, Busan, Korea
}

\section{소아 일측성 감각신경성 난청의 치료}

\author{
정 성 욱·김 리 석 \\ 동아대학교 의과대학 이비인후-두경부외과학교실
}

\author{
Received March 10, 2016 \\ Revised June 9, 2016 \\ Accepted June 17, 2016 \\ Address for correspondence \\ Lee-Suk Kim, MD, PhD \\ Department of Otorhinolaryngology- \\ Head and Neck Surgery, \\ College of Medicine, \\ Dong-A University, \\ 26 Daesingongwon-ro, Seo-gu, \\ Busan 49201, Korea \\ Tel $+82-51-240-5428$ \\ Fax $+82-51-253-0712$ \\ E-mailkklsolkor@chol.com
}

Every one of a thousand of neonates is born with unilateral sensorineural hearing loss (UHL) and the prevalence of UHL increases in school aged children due to delayed-onset or acquired HL. Some studies showed that UHL impacted on speech-language development and school performance adversely. Therefore, appropriate intervention for UHL children may be needed. Treatment approach for UHL children can be chosen depending on the degree of HL. Cochlear implantation (CI) provides benefits of binaural hearing including better speech perception in noise and sound localization to children with acquired severe-to-profound UHL. However, children with congenital severe-to-profound UHL and long duration of HL gain the unfavorable benefit from CI. Contralateral routing of signal hearing aid and bone anchored hearing device should not be recommended for young children with UHL because these devices can introduce noise to normal hearing ear and young children are not able to competently monitor their listening environment and to make judgments about when these devices may be appropriate. Conventional hearing aid (HA) has the potential of providing binaural hearing for UHL children with amplifiable hearing and the studies realized the binaural hearing when UHL children wore HA. However adherence to HA is poor because of some reasons including parents' reluctance to fit a HA in the presence of a normal-hearing ear and stigma effect. Long term follow up data of these interventions for UHL children are lacking. So fully informed consent is required during decision making process for UHL children until the concrete guideline of intervention for UHL children is established.

Korean J Otorhinolaryngol-Head Neck Surg 2016;59(10):699-705

Key Words Child · Sensorineural hearing loss · Unilateral hearing loss.

\section{서 론}

영구적인 일측성 감각신경성 난청은 신생아 1000 명당 약 1 명에서 발생한다. ${ }^{1,2)}$ 그리고 지연성 난청의 발생과 외상, 감염, 이독성 약물 사용 등에 기인한 후천성 난청의 발생으로 학령 기에는 약 0.1 5\% 정도가 일측성 감각신경성 난청을 가지는 것으로 보고되었다. ${ }^{3,4)}$ 소아 일측성 감각신경성 난청의 원인은 와우신경부전(cochlear nerve deficiency)이 가장 흔하며, 그 외 거대세포바이러스 감염, 뇌막염, 두부 외상 등이 있다. ${ }^{5)}$ 일
측성 난청의 진단 연령은 과거에는 평균 5.5 세 정도였으나, ${ }^{6}$ 신생아 청각선별검사가 도입된 이후 신생아 일측성 난청의 진 단이 크게 증가하였다.

과거에는 대부분의 소아 일측성 난청 환자가 적절한 말·언 어 발달을 이루기 때문에 특별한 치료가 필요 없다고 생각하 였고, 듣기에 어려움이 있는 경우에는 교실에서 앞자리에 좌 석을 배치하거나 FM 기기를 사용하는 정도의 소극적 개입을 하는 정도였다. ${ }^{7-9)}$ 그러나 1980년대 이후 여러 연구에서 일측 성 난청을 가진 아동의 많은 수가 건청 아동에 비해 말.언어 
발달 지연, 학업 성취도 저하, 그리고 사회·정서적 측면의 어려 움(social-emotional difficulty)을 겪는 것으로 보고하고 있 어, ${ }^{10-12)}$ 소아 일측성 난청의 치료에 대한 관심이 증가하고 있 다. 그러나 양측성 감각신경성 난청을 가진 소아 환자에 대한 치료 방침이 구체적으로 확립되어 있는 것이 비해, 소아 일측 성 난청에 대한 치료 방침은 아직 확립되어 있지 않다. 즉 일 측성 감각신경성 난청을 가진 소아 중 치료가 필요한 대상자 의 선정 기준과 치료 방법의 선택 등 구체적인 지침은 아직 정 립되어 있지 않다. 소아 일측성 감각신경성 난청과 관련하여 최근까지 발간된 문헌 고찰을 통해, 일측성 난청이 아동의 발 달에 미치는 영향과 치료 방침에 대해 고찰해 보고자 한다.

\section{일측성 난청이 아동에게 미치는 영향}

일측성 난청을 가진 아동은 건청 아동에 비해 말.언어 발달 이 저하되는 경향이 있으며 이러한 현상은 영유아기부터 시작 되는 것으로 보고되고 있다. ${ }^{13-15)}$ 일측성 난청을 가진 영아 34 명과 건청 대조군을 대상으로 Infant-Toddler Meaningful Auditory Integration Scale로 평가한 청각적 수행력과 전언 어기 발성의 정도를 평가한 연구에 따르면, 일측성 난청을 가 진 영아군에서는 $21 \%$ 가 청각적 수행력의 지체를 보이고 $41 \%$ 가 전언어기 발성의 지체를 보이는 반면 건청군에서는 각각 4\%에서만 지체를 보여, 일측성 난청이 말.언어 발달에 미치 는 부정적 영향은 영아기부터 나타난다고 하였다. ${ }^{13)}$ 유아기 일측성 난청 아동의 말-언어 발달에 대한 연구에서도 유사 한 결과를 보고하였다. 4 6세의 고·심도 일측성 난청 아동 들을 대상으로 언어 기술(language skill)을 평가한 한 연구 에 따르면 일측성 난청 아동은 건청 대조군에 비해 언어 발 달이 유의하게 지연되어 있었다고 하였고, ${ }^{14)}$ 역치 $30 \mathrm{~dB} \mathrm{HL}$ 이상의 일측성 난청을 가진 영유아 31 명을 대상으로 한 연구 에서도 이들의 두 단어 발화가 건청 아동에 비해 늦다고 하 였다. ${ }^{15)}$ 다른 환자-대조군 연구에서 일측성 난청 아동군이 건청 대조군에 비해 언어 발달과 어휘력이 부진한 것으로 보 고하였다. ${ }^{16)}$

소아기의 일측성 난청은 아동의 말.언어 발달 외에 학업 성 적에도 부정적 영향을 미친다는 보고가 있다. 일측성 난청을 가진 60 명의 아동을 대상으로 한 Bess 등 $^{17)}$ 의 연구에 따르 면, 일측성 난청 아동의 $35 \%$ 가 한 학년 이상 유급하였는데, 이것은 건청 아동 유급률인 $3.5 \%$ 의 10 배에 해당한다고 하였 다. 다른 연구에서도 일측성 난청 아동들이 한 학년 이상의 빈번한 유급과 추가적인 개인 교육을 받는 등 학업적 어려움 을 겪는다고 보고하였다. ${ }^{18-20)}$ 최근의 코호트 연구에서는 일 측성 난청을 가진 아동은 어휘력, 구어 언어 능력, 그리고 언
어 지능(verbal IQ)과 전체 지능(full scale $\mathrm{IQ}$ )이 건청 아동에 비해 낮은 것으로 보고하였다. ${ }^{21)}$ 또한 일측성 난청을 가진 아 동과 청소년들은 교우 관계에서 위축되고 스스로 활동을 제 한하는 경향이 있으며, 스스로 심각한 장애를 가지고 있고 삶의 질이 낮다고 인지한다는 보고도 있다. ${ }^{22,23)}$

일측성 난청 아동이 말-언어 발달과 학업에 어려움을 겪는 이유는 양이청의 처리(binaural processing) 능력이 부족하기 때문이다. ${ }^{17,24-27)}$ 음원에서 발생한 소리는 머리 가림 효과(head shadow effect)에 의해 서로 다른 시간에 서로 다른 강도로 두 귀에 도달하게 되는데, 소리가 두 귀에 도달하는 미세한 시간의 차이(interaural time difference, ITD)와 두 귀에 도달 하는 소리 크기의 미세한 차이(interaural level difference, ILD)를 대뇌에서 분석하는 것을 양이청의 처리라고 하며, 이 를 통해 소리 방향 찾기(sound localization)와 소리 분리 (sound segregation), 즉 배경 소음 속에서 듣고자 하는 말소 리만을 구분하는 것이 가능해진다. 양이청의 처리는 상올리브 핵(superior olivary complex)이 담당하는데, 이 중 ILD의 처 리는 외측상올리브(lateral superior olive), ITD의 처리는 내 측상올리브(medial superior olive)가 담당하며 이들 핵 속 에 위치한 $\mathrm{GABA}_{\mathrm{B}}$ 수용체의 활성에 의해 조절되는 것으로 알려져 있다. ${ }^{28)}$

실제로 일측성 난청을 가진 아동과 건청 아동을 대상으로 한 여러 연구에서, 일측성 난청을 가진 아동은 건청 아동에 비해 소리 방향 찾기(특히 난청 귀 쪽 방향에서 기원한 소리) 능력의 저하, ${ }^{17)}$ 소음환경에서 말지각의 저하 ${ }^{17,24,25)}$ 를 겪는 것 으로 보고되었다. 일측성 난청으로 인한 양이청의 결함으로 인해 일상 생활 환경에서 타인의 말소리를 이해하는 데 어려 움을 겪게 되고, 이는 말·언어 능력과 학업 성취도 저하를 초래한다. ${ }^{29)}$ 더욱이 아동은 교실, 복도, 운동장 등에서 대부분 의 시간을 보내는데, 환자 본인과 대화 상대방 모두 정지해 있 지 않고 지속적으로 움직이는 상황이 많고 주변 소음이 비교 적 많은 환경에서 생활하기 때문에, 소리 방향 찾기 능력 저 하와 소음환경에서의 말지각 저하로 인한 의사 소통의 장애 가 성인에 비해 더욱 크게 나타날 수 있다. ${ }^{5)}$

이와 같이 여러 연구에서 일측성 난청이 아동의 말·언어 발 달과 학업 성취도에 부정적 영향을 미친다고 보고하고 있으 나, 이와 반대로 일측성 난청을 가진 아동의 말-언어 발달과 학업 성적이 건청 아동에 비해 유의한 차이가 없음을 보고하 는 연구들도 있다. ${ }^{7,30)}$

\section{소아 일측성 난청의 치료}

앞서 살펴본 바와 같이 많은 일측성 난청 아동들이 말-언 
어 발달의 지체, 학업 성취도 저하, 사회·정서적 어려움을 겪 기는 하지만, 이와 반대로 정상적인 말 - 언어 발달과 학업 성 취도를 이루는 경우도 있다. ${ }^{7,1721,22,30)}$ 또한 일측성 난청 아동 은 반대 측에 정상 귀를 가지고 있기 때문에, 일측성 난청으 로 인한 청각적 문제는 양측성 난청과 달리 주변 소음이 있 는 상황, 여러 화자와의 대화 상황, 난청 귀 쪽에 화자가 위치 하는 상황 등 특정 듣기 환경에 국한하여 나타난다. 따라서 모든 일측성 난청 아동이 치료가 필요하다고 보기는 어렵다. 미국 청각학회(American Academy of Audiology)에서 제안 한 pediatric amplification protocol ${ }^{31)}$ 에서도, 일측성 난청을 가진 아동 중 일부에서 소리의 증폭(amplification)이 필요 하며 그 시행 여부는 아동의 청력, 발달 상황, 의사소통, 교육 적 요인은 물론 아동과 부모의 선호도를 고려하여 환자 개개 인의 상황에 따라 결정하여야 한다고 권고하고 있다. 이와 같이 아직은 모든 일측성 난청 환자에 대해 치료를 권고하고 있지는 않으며 일측성 난청 아동 중 치료가 필요한 대상자의 선정 기준과 치료 방법의 선택 기준도 확립되어 있지 않다. 따라서 일측성 난청 아동에 대한 치료 여부는 일측성 난청이 아동에게 미칠 잠재적 영향, 적용 가능한 치료 방법의 종류와 장단점 등에 대한 정보를 보호자에게 제공하고 충분한 상담 을 통해 결정하여야 할 것이다.

일측성 난청의 치료에 적용될 수 있는 방법에는 보청기, 인 공와우, contralateral routing of signal hearing aid(CROS 보청기), bone anchored hearing aid(BAHA) 등이 있다. 이 중 보청기와 인공와우는 난청 귀를 듣게 하는 방법이고 $\mathrm{CROS}$ 보청기와 BAHA는 건측 귀로 소리를 보내어 듣게 하는 방법 이다. 이러한 다양한 치료 방법의 선택에 있어서 우선적 고려 사항은 난청의 정도이다. ${ }^{5,12)}$ 일측성 난청을 가진 아동의 난청 귀의 청력 역치는 경도에서 심도까지 다양하게 나타나지만, 다수의 아동은 고·심도 난청을 가지는 것으로 보고되고 있 다. ${ }^{22,23)} U$ mansky 등 ${ }^{22)}$ 에 따르면, 7 12세의 35명의 일측성 감 각신경성난청 아동 중 21 명(60\%)이 고· 심도 난청이었고, Rachakonda 등 23 에 따르면 13 18세의 63명의 일측성 감각신경 성난청 청소년 중에서 40명(63\%)이 고· 심도 난청을 가지고 있 었다고 하였다. 또한 일측성 난청 아동들은 난청의 정도가 심할수록 소음하 말지각 능력이 부족하고 소리 방향 찾기 능 력이 저하되는 것으로 보고되었다. ${ }^{17)}$

이와 같이 유병률이 높고 아동의 듣기 능력에 미치는 영향 이 큰 고·심도 일측성 난청의 치료에 대해 먼저 살펴보고, 이 후에 중등고도 이하의 일측성 난청의 치료에 대해 알아보고 자 한다.

\section{고·심도 소아 일측성 난청의 치료}

고·심도 일측성 난청을 가진 소아에게 적용할 수 있는 치료 법은 $\mathrm{CROS}$ 보청기, $\mathrm{BAHA}$, 그리고 인공와우이식이 있다.

\section{$\mathrm{CROS}$ 보청기와 BAHA}

$\mathrm{CROS}$ 보청기와 BAHA는 난청 귀로 들어오는 청각 정보를 건측 귀로 전해주는 장치이기 때문에, 난청 귀 쪽으로 말소 리 정보가 들어오는 경우에는 도움이 되지만 소음이 들어오 는 경우에는 이 소음이 건측 귀로 전달되어 건측 귀가 말소 리 정보를 지각하는 데 방해가 되는 단점이 있다.22)

경도에서 심도에 이르는 다양한 일측성 난청을 가진 아동 들을 대상으로 $\mathrm{CROS}$ 보청기의 효과를 조사한 연구에 따르 면, 소음 상황에서 $\mathrm{CROS}$ 보청기 착용이 말지각에 도움이 되 지 않으며 건측 귀를 부분적으로 폐쇄하여 건측 귀의 듣기를 방해하는 단점이 있다고 하였다. ${ }^{33)}$ 반면 BAHA는 건측 귀를 폐쇄하지 않고 소리의 질이 좋은 장점이 있으며 심도 일측성 난청 아동에서 소음하 말지각과 삶의 질을 향상시킨다는 보고 가 있다. ${ }^{34,35} 23$ 명의 심도 일측성 난청 아동을 대상으로 BAHA 의 효과를 조사한 연구에 따르면, BAHA 이식 후 소음하 말 지각 검사와 설문조사에서 유의한 개선이 있었다고 하였고, ${ }^{34}$ $\mathrm{BAHA}$ 이식을 받은 심도 일측성 난청 아동 8명을 대상으로 한 연구에서는 대부분의 아동이 다자간 대화, 음악 감상, TV 시청, 농 귀 측에 앉은 사람과의 대화에서 도움이 된다고 하 였다. ${ }^{35)}$ 이러한 장치들은 주변의 소음 상황을 파악하여 선택 적으로 사용할 때 효과가 있으므로 청소년에서는 도움이 될 수 있으나 상황 판단 능력이 매우 부족한 어린 소아들에서는 적절하지 않다. ${ }^{12,26)}$ 또한 난청 귀를 듣게 하는 장치가 아니므 로, 일측성 난청의 본질적인 결함인 양이청을 회복하지는 못 한다.

\section{인공와우이식}

인공와우이식은 난청 귀를 듣게 하므로 양이청을 회복하게 하는 근본적인 치료라고 할 수 있다. ${ }^{26)}$ 성인 일측성 고·심도 난청 환자에게 시행한 인공와우이식에 대해서는 다수의 연 구들이 있으며 좋은 결과들을 보고하고 있다. 최근의 메타 분석에 따르면, 성인 일측성 농 환자에서 인공와우이식은 소 음하 말지각, 소리 방향 찾기, 그리고 주관적인 듣기 능력을 유의하게 개선시킨다. ${ }^{36}$ 반면 소아 일측성 고· 심도 난청 환자 에게 시행한 인공와우이식에 대한 보고들은 매우 다양한 결 과를 보여주고 있다.

Hassepass 등 ${ }^{377}$ 은 3 명의 후천성 일측성 심도 난청 아동에 게 시행한 인공와우이식의 결과를 보고하였다. 이 보고에는 미로염으로 급성 난청이 발생한 10세 3개월의 아동(농기간 5 
개월), 전정도수관확장증으로 인한 진행성 난청이 농에 이른 11 세 9 개월의 아동(농기간 18 개월), 그리고 난청 발생 시점과 원인이 명확치 않은 4세 4개월의 아동(출생 시 이음향방사검 사에서 정상 반응을 보인 것을 근거로 후천성 난청으로 추정 하며 농기간은 미상)이 포함되었는데, 3 명의 아동 모두 수술 후 12개월에 소음하 말지각과 소리 방향 찾기 능력이 향상되 었고 Speech, Spatial, and Qualities of Hearing Scale 설문에 서도 수술 전에 비해 향상된 듣기 능력을 보여주었다. Plontke 등 ${ }^{38)}$ 은 측두골 골절로 인해 언어습득 후 일측 청력을 소실한 8세 소아에게 조기에 인공와우이식을 시행하여 소음하 말지 각과 소리 방향 찾기 능력이 개선되고 환자의 주관적 만족도 가 높았다고 보고하였다. 반면 3명의 선천성 일측성 농 아동 에게 인공와우이식을 시행한 보고에서는 상반된 결과를 보여 주었다. ${ }^{39)} 4.5$ 세에 수술한 아동은 도움이 되지 않아 인공와우 를 사용하지 않는다고 하였고, 6.8 세에 수술한 아동은 소리 자극을 진동으로 감지하며 소음하 말지각과 소리 방향 찾기 능력에 개선이 없다고 하였다. 1 세 5 개월에 수술한 아동은 공 식적인 말-언어 평가를 할 수 없어 이식 후 결과를 제시하지 않았다. 이 연구에서는 9 세에 뇌막염이 발생하여 일측 청력 을 소실한 아동에서 5 주 후 인공와우이식을 시행한 결과도 함께 보고하였는데, 수술 후에 소음하 말지각과 소리 방향 찾 기 능력이 개선되었다고 하였다. ${ }^{37)}$ 최근에 Arndt 등 ${ }^{40}$ 은 13 명 의 일측성 농 아동에게 시행한 인공와우이식의 결과를 보고 하였다. 거대세포바이러스 감염으로 인해 선천성 일측성 농 이 발생한 두 아동에게 각각 4.3세와 13.8세에 인공와우이식 을 시행한 결과 두 아동 모두 소음하 말지각과 소리 방향 찾 기에 있어서 유의한 진전이 없으며, 4.3세에 수술을 받은 아동 은 학교에서만 인공와우를 사용하고, 13.8 세에 수술받은 아 동은 인공와우를 사용하지 않는다고 하였다. 반면 언어습득 기 농 2명과 언어습득 후 농 9 명의 경우 인공와우이식 후 소 음하 말지각과 소리 방향 찾기 능력에 유의한 개선이 있었다 고 하였다. 또한 후천성 일측성 농 아동들은 난청 기간이 짧 은 아동이 난청 기간이 긴 아동에 비해 수행력이 우수하였다 고 하였다. 비록 제한된 숫자의 보고이기는 하지만, 이상의 보 고들을 종합하면 후천성 일측성 난청을 가진 아동은 인공와 우이식 후 소리 방향 찾기 능력과 소음하 말지각과 같은 양이 청의 능력이 향상되지만, 선천성 일측성 난청 아동에서 난청 기간이 짧지 않은 경우에는 인공와우이식의 결과가 좋지 못 하다고 할 수 있다.

이와 같이 선천성 일측성 고·심도 난청 아동에서 난청 기간 이 긴 경우에 인공와우이식의 결과가 나쁜 이유를 설명할 수 있는 이론 중 하나는 귀 선호 증후군(aural preference syndrome)이다. 정상인에서 우측 귀의 청각 정보는 좌측 청각피
질로, 좌측 귀의 청각 정보는 우측 청각피질로 주로 전달된 다. 즉 정상인의 양측 대뇌 청각피질은 반대측 귀를 선호한 다. 그런데 발달 초기에 일측 농이 발생하면, 중추청각로는 건측 귀를 향해 재편(reorganization)되고 농 귀를 향해서는 약한 central representation을 보이는데 이것을 귀 선호 증후 군이라고 한다. ${ }^{541,42)}$ 다시 말해 귀 선호 증후군은 일측성 난 청 환자에서 양측 청각피질이 모두 건측 귀를 선호하게 되는 현상이며, 난청 귀에 대한 치료 후에도 양측 청각피질의 비정 상적인 건측 귀 선호 현상이 교정되지 않는다. ${ }^{5)}$ 이러한 현상 은 고양이를 이용한 동물 실험 ${ }^{41}$ 과 첫 번째 인공와우이식을 조기에 시행한 순차적 양측 인공와우이식 환자들을 대상으 로 한 연구 ${ }^{5,42}$ 에서 증명된 바 있다.

선천성 일측성 난청 아동도 조기 인공와우이식을 시행하여 난청 기간을 줄이면 그 결과가 양호할 가능성도 있으나, ${ }^{26)}$ 이 와 관련된 문헌 보고는 아직 없는 상황이다. 최근에 Friedmann 등 ${ }^{43}$ 이 4명의 일측성 난청 아동에게 시행한 인공와우 이식의 결과를 보고하였는데, 각각 10세와 6세 때 수술한 두 명의 아동은 결과가 매우 부진하였으나 비교적 이른 시기인 3세 때 수술한 아동은 수술 후 3개월이 지난 시점에 이식 귀 의 단음절 단어인지 점수가 $32 \%$, 문장인지 점수가 $70 \%$ 로 개선되었고 일상생활에서 소리가 어디서 나는지를 부모에게 더 이상 묻지 않는다고 하였다. 이 문헌 보고에는 생후 11 개 월의 매우 이른 시기에 인공와우이식을 시행한 일측성 난청 아동도 포함되었으나, 아쉽게도 이식 후 경과 관찰기간이 짧 아 말-언어 평가 결과를 제시하지는 않았다. 선천성 일측성 난청 아동 중 고·심도 난청의 비율이 높다는 점, ${ }^{22,23)}$ 이들에 게 양이청을 제공할 수 있는 근본적인 치료가 인공와우이식 이라는 점, ${ }^{26)}$ 그리고 난청 기간이 긴 선천성 일측성 난청 아동 에게 시행한 인공와우이식의 결과가 좋지 못하다는 점 ${ }^{39,40,43)}$ 등을 고려하면, 이러한 아동에게 시행한 조기 인공와우이식 의 효과를 밝히기 위한 많은 연구가 필요하다고 할 수 있다.

선천성 일측성 고·심도 난청의 조기 인공와우이식과 관련 하여 다음의 두 가지 고려 사항을 염두에 둘 필요가 있다. 첫 번째는 대상자 선정이 어렵다는 점이다. 선천성 일측성 고. 심도 난청을 가지고 태어나더라도 이후 성인이 되어 특별한 어려움 없이 생활하는 사람도 있는데, 선천성 일측성 고·심 도 난청을 가진 아동이 성인이 되었을 때 난청으로 인해 어 려움을 겪게 될지 여부를 영유아기에 미리 예측하여 인공와 우이식의 시행여부를 결정하는 것이 현재로서는 불가능하기 때문이다. ${ }^{26,43)}$ 두 번째 고려할 점은 선천성 일측성 고·심도 난 청 아동들은 인공와우이식의 불량 예후인자 중 하나인 와우 신경부전을 가지고 있을 가능성이 높다는 점이다. ${ }^{40,44)}$ Purcell 등 ${ }^{44}$ 의 보고에 따르면, 84 명의 선천성 고·심도 일측성 난청 
아동의 골성와우신경관(bony cochlear nerve canal)의 너비 가 평균 $1.78 \mathrm{~mm}$ 로 건측 귀의 평균 너비인 $2.12 \mathrm{~mm}$ 에 비해 유의하게 좁았다고 하였다. 또한 Arndt 등 ${ }^{40)}$ 은 24 명의 선천 성 일측 농 아동 중 14 명에서 와우신경부전이 동반되었다고 하였다.

\section{중등고도 이하 소아 일측성 난청의 치료}

\section{보청기}

보청기는 이론적으로 중등고도 이하의 난청에서는 유용하 게 적용될 수 있는 도구이다. 하지만 일측성 난청을 가진 아 동에서의 보청기 효과에 대한 연구는 충분하지는 않으며, 보 청기 사용 대상을 정하는 청력 기준도 확립되어 있지 않다.

Briggs 등 ${ }^{45)}$ 은 경도에서 중등고도에 이르는 일측성 난청을 가진 학령기 아동을 대상으로 시행한 소음하 말지각 검사의 결과를 보고하였다. 조용한 환경과 소음 환경 모두에서 보청 기 착용이 공식적인 말지각 검사의 점수를 향상시키지는 못 하였으나 주관적 만족도를 평가하는 설문에서는 보청기 사 용이 일상 생활과 학업 등 다양한 영역에서 유의한 이득이 있 는 것으로 조사되었다. 일측성 난청을 가진 학령기 아동의 소 리 방향 찾기 능력을 검사한 다른 연구에서는 보청기 사용이 소리 방향 찾기 능력을 향상시키며 보청기 착용을 시작한 나 이가 어릴수록 효과가 크다고 하였다. ${ }^{46)}$ 이와 같이 중등고도 이하의 일측성 난청을 가진 경우에는 보청기 착용이 주관적 인 듣기 능력의 향상과 소리 방향 찾기 능력의 향상 등 도움 이 되지만, 실제로 보청기 착용에 대한 순응도는 높지 않다. Kiese-Himmel ${ }^{15)}$ 은 31 명의 일측성 난청 아동을 대상으로 한 연구에서, 중등고도 이하의 난청을 가진 경우 $81 \%$ 의 아 동이 보청기를 사용하지만, 고·심도 난청 아동의 경우 보청 기를 잘 사용하지 않거나 전혀 사용하지 않는다고 하였다. Davis 등 ${ }^{47)}$ 은 보청기를 처방받은 27 명의 일측성 난청 아동 을 대상으로 한 연구에서, $26 \%$ 는 항상 보청기를 착용하고 $4 \%$ 는 학교에서만 착용하며 $50 \%$ 는 전혀 착용하지 않는다고 하였다. 일측성 난청 아동이 보청기를 처방받더라도 지속적 으로 사용하지 않는 것은 보청기 처방에 대한 의사의 소극적 태도와 반대측 정상 귀의 존재에 기인할 수 있다. ${ }^{5)}$ 보청기를 전혀 착용하지 않는 아동의 부모들은 아동이 보청기를 착용 하지 않는 주된 이유가 보청기 착용자라고 하는 낙인(stigma) 과 주변의 놀림 때문으로 생각한다는 보고도 있다. ${ }^{12)}$

\section{결 론}

비록 정상적인 발달을 보이는 경우도 있으나 많은 일측성
난청 아동은 말·언어 발달, 학업, 사회·정서적 측면에서 어려 움을 겪을 가능성이 크기 때문에 적절한 치료적 개입이 필요 하다고 할 수 있다. 고·심도 난청의 경우 인공와우이식, $\mathrm{CROS}$ 보청기, BAHA가 치료 방법이 될 수 있다. 후천성 고·심도 난 청 아동은 인공와우이식을 통해 소음하 말지각과 소리 방향 찾기 능력이 개선되나 선천성 고·심도 난청 아동이 난청 기간 이 긴 경우에는 인공와우이식의 효과가 부진하다. 또한 소아 일측성 고·심도 난청 아동은 인공와우이식의 불량 예후 인 자인 와우신경부전을 동반할 가능성이 높으므로 영상검사를 통해 이를 반드시 확인하여야 한다. $\mathrm{CROS}$ 보청기와 BAHA 는 건측 귀를 듣게 하는 장치이므로 양이청을 제공하지는 못 한다. 또한 기기를 착용한 귀 쪽으로 소음이 들어올 때 이 소 음이 건측 귀로 전달되어 말지각을 방해할 수 있기 때문에 주 변 소음 환경을 잘 판단하여 기기 사용여부를 결정하기 어려 운 어린 소아에는 적합하지 않다. 중등고도 이하 일측성 난청 아동에서는 보청기가 도움이 될 수 있으나 순응도는 낮다.

여러 연구에도 불구하고 일측성 난청 아동 중 치료가 필요 한 대상자의 선정 기준, 치료 시기, 치료 방법의 선택 등 중요 한 치료 지침들이 아직 확립되어 않다. 신생아 청각선별검사 의 보편화와 함께 일측성 난청의 조기 진단이 크게 증가하고 있는 만큼 일측성 난청 아동의 치료 방침을 확립하기 위한 더 많은 연구가 필요하며, 현 시점에서 일측성 난청 아동의 치료는 미국 청각 학회의 권고와 같이 아동의 청력, 발달 상 황, 의사소통, 교육적 요인은 물론 아동과 부모의 선호도 등 을 종합적으로 고려하여 환자 개개인의 상황에 따라 신중하 게 결정하여야 할 것이다.

\section{Acknowledgments}

This study was supported by research funds from Dong-A University.

\section{REFERENCES}

1) Barsky-Firkser L, Sun S. Universal newborn hearing screenings: a three-year experience. Pediatrics 1997;99(6):E4.

2) Finitzo T, Albright K, O'Neal J. The newborn with hearing loss: detection in the nursery. Pediatrics 1998;102(6):1452-60.

3) Shargorodsky J, Curhan SG, Curhan GC, Eavey R. Change in prevalence of hearing loss in US adolescents. JAMA 2010;304(7): $772-8$.

4) Niskar AS, Kieszak SM, Holmes A, Esteban E, Rubin C, Brody DJ. Prevalence of hearing loss among children 6 to 19 years of age: the Third National Health and Nutrition Examination Survey. JAMA 1998;279(14):1071-5.

5) Gordon K, Henkin Y, Kral A. Asymmetric hearing during development: the aural preference syndrome and treatment options. Pediatrics 2015;136(1):141-53.

6) Bess FH, Tharpe AM. Unilateral hearing impairment in children. Pediatrics 1984;74(2):206-16.

7) Hallmo P, Møller P, Lind O, Tonning FM. Unilateral sensorineural hearing loss in children less than 15 years of age. Scand Audiol 1986; 
15(3):131-7.

8) Lieu JE, Tye-Murray N, Karzon RK, Piccirillo JF. Unilateral hearing loss is associated with worse speech-language scores in children. Pediatrics 2010;125(6):e1348-55.

9) Newman CW, Jacobson GP, Hug GA, Sandridge SA. Perceived hearing handicap of patients with unilateral or mild hearing loss. Ann Otol Rhinol Laryngol 1997;106(3):210-4.

10) Tharpe AM. Unilateral and mild bilateral hearing loss in children: past and current perspectives. Trends Amplif 2008;12(1):7-15.

11) Lieu JE. Speech-language and educational consequences of unilateral hearing loss in children. Arch Otolaryngol Head Neck Surg 2004; 130(5):524-30.

12) McKay S, Gravel JS, Tharpe AM. Amplification considerations for children with minimal or mild bilateral hearing loss and unilateral hearing loss. Trends Amplif 2008;12(1):43-54.

13) Kishon-Rabin L, Kuint J, Hildesheimer M, Ari-Even Roth D. Delay in auditory behaviour and preverbal vocalization in infants with unilateral hearing loss. Dev Med Child Neurol 2015;57(12):1129-36.

14) Borg E, Risberg A, McAllister B, Undemar BM, Edquist G, Reinholdson AC, et al. Language development in hearing-impaired children. Establishment of a reference material for a 'Language test for hearing-impaired children', LATHIC. Int J Pediatr Otorhinolaryngol 2002;65(1):15-26.

15) Kiese-Himmel C. Unilateral sensorineural hearing impairment in childhood: analysis of 31 consecutive cases. Int J Audiol 2002;41 (1):57-63.

16) Klee TM, Davis-Dansky E. A comparison of unilaterally hearingimpaired children and normal-hearing children on a battery of standardized language tests. Ear Hear 1986;7(1):27-37.

17) Bess FH, Tharpe AM, Gibler AM. Auditory performance of children with unilateral sensorineural hearing loss. Ear Hear 1986;7(1):20-6.

18) Bovo R, Martini A, Agnoletto M, Beghi A, Carmignoto D, Milani $\mathrm{M}$, et al. Auditory and academic performance of children with unilateral hearing loss. Scand Audiol Suppl 1988;30:71-4.

19) Lieu JE, Tye-Murray N, Fu Q. Longitudinal study of children with unilateral hearing loss. Laryngoscope 2012;122(9):2088-95.

20) Kesser BW, Krook K, Gray LC. Impact of unilateral conductive hearing loss due to aural atresia on academic performance in children. Laryngoscope 2013;123(9):2270-5.

21) Lieu JE. Unilateral hearing loss in children: speech-language and school performance. B-ENT 2013;Suppl 21:107-15.

22) Umansky AM, Jeffe DB, Lieu JE. The HEAR-QL: quality of life questionnaire for children with hearing loss. J Am Acad Audiol 2011;22(10):644-53.

23) Rachakonda T, Jeffe DB, Shin JJ, Mankarious L, Fanning RJ, Lesperance MM, et al. Validity, discriminative ability, and reliability of the hearing-related quality of life questionnaire for adolescents. Laryngoscope 2014;124(2):570-8.

24) Hartvig Jensen J, Johansen PA, Børre S. Unilateral sensorineural hearing loss in children and auditory performance with respect to right/left ear differences. Br J Audiol 1989;23(3):207-13.

25) Reeder RM, Cadieux J, Firszt JB. Quantification of speech-in-noise and sound localisation abilities in children with unilateral hearing loss and comparison to normal hearing peers. Audiol Neurootol 2015; 20 Suppl 1:31-7.

26) Boyd PJ. Potential benefits from cochlear implantation of children with unilateral hearing loss. Cochlear Implants Int 2015;16(3):121-36.

27) Ruscetta MN, Arjmand EM, Pratt SR. Speech recognition abilities in noise for children with severe-to-profound unilateral hearing impairment. Int J Pediatr Otorhinolaryngol 2005;69(6):771-9.

28) Grothe B, Koch U. Dynamics of binaural processing in the mammalian sound localization pathway--the role of GABA(B) receptors. Hear Res 2011;279(1-2):43-50.
29) Welsh LW, Welsh JJ, Rosen LF, Dragonette JE. Functional impairments due to unilateral deafness. Ann Otol Rhinol Laryngol 2004;113(12): 987-93.

30) Keller WD, Bundy RS. Effects of unilateral hearing loss upon educational achievement. Child Care Health Dev 1980;6(2):93-100.

31) American Academy of Audiology. Pediatric Amplification Protocol (October 2003) [cited 2015 Jun 5]. Available from: URL: http://www. audiology.org.

32) Kenworthy OT, Klee T, Tharpe AM. Speech recognition ability of children with unilateral sensorineural hearing loss as a function of amplification, speech stimuli and listening condition. Ear Hear 1990; 11(4):264-70.

33) Updike CD. Comparison of FM auditory trainers, CROS aids, and personal amplification in unilaterally hearing impaired children. J Am Acad Audiol 19945(3):204-9.

34) Christensen L, Richter GT, Dornhoffer JL. Update on boneanchored hearing aids in pediatric patients with profound unilateral sensorineural hearing loss. Arch Otolaryngol Head Neck Surg 2010;136(2):175-7.

35) Doshi J, Banga R, Child A, Lawrence R, Reid A, Proops D, et al. Quality-of-life outcomes after bone-anchored hearing device surgery in children with single-sided sensorineural deafness. Otol Neurotol 2013;34(1):100-3.

36) Blasco MA, Redleaf MI. Cochlear implantation in unilateral sudden deafness improves tinnitus and speech comprehension: metaanalysis and systematic review. Otol Neurotol 2014;35(8):1426-32.

37) Hassepass F, Aschendorff A, Wesarg T, Kröger S, Laszig R, Beck $\mathrm{RL}$, et al. Unilateral deafness in children: audiologic and subjective assessment of hearing ability after cochlear implantation. Otol Neurotol 2013;34(1):53-60.

38) Plontke SK, Heider C, Koesling S, Hess S, Bieseke L, Goetze G, et al. Cochlear implantation in a child with posttraumatic single-sided deafness. Eur Arch Otorhinolaryngol 2013;270(5):1757-61.

39) Távora-Vieira D, Rajan GP. Cochlear implantation in children with congenital and noncongenital unilateral deafness: a case series. Otol Neurotol 2015;36(2):235-9.

40) Arndt S, Prosse S, Laszig R, Wesarg T, Aschendorff A, Hassepass F. Cochlear implantation in children with single-sided deafness: does aetiology and duration of deafness matter? Audiol Neurootol 2015; 20 Suppl 1:21-30.

41) Kral A, Hubka P, Heid S, Tillein J. Single-sided deafness leads to unilateral aural preference within an early sensitive period. Brain 2013;136(Pt 1):180-93.

42) Gordon KA, Wong DD, Papsin BC. Bilateral input protects the cortex from unilaterally-driven reorganization in children who are deaf. Brain 2013;136(Pt 5):1609-25.

43) Friedmann DR, Ahmed OH, McMenomey SO, Shapiro WH, Waltzman SB, Roland JT Jr. Single-sided deafness cochlear implantation: candidacy, evaluation, and outcomes in children and adults. Otol Neurotol 2016;37(2):e154-60.

44) Purcell PL, Iwata AJ, Phillips GS, Paladin AM, Sie KC, Horn DL. Bony cochlear nerve canal stenosis and speech discrimination in pediatric unilateral hearing loss. Laryngoscope 2015;125(7):1691-6.

45) Briggs L, Davidson L, Lieu JE. Outcomes of conventional amplification for pediatric unilateral hearing loss. Ann Otol Rhinol Laryngol 2011;120(7):448-54.

46) Johnstone PM, Nábělek AK, Robertson VS. Sound localization acuity in children with unilateral hearing loss who wear a hearing $d$ in the impaired ear. J Am Acad Audiol 2010;21(8):522-34.

47) Davis AC, Reeve C, Hind S, Bamford J. Children with mild and unilateral hearing impairment. In: Seewald RC, Gravel JS, editors. A Sound Foundation Through Early Amplification. USA: Proceedings of the Second International Conference;2001. p.179-84. 
Management of Pediatric Unilateral Sensorineural Hearing Loss I Jeong SW, et al.

\section{정답 및 해설}

답 (5)

해 설 후비공비용은 대체로 일측성으로 발생하며 남아에서 호발하는 경향이 있다. 수술적 치료로 과거에는 Caldwell-Luc 수 술법을 사용하지만 내시경수술이 도입되면서 재발률이 현저하게 떨어졌다. 상악동에서 가장 많이 발생하나 드물게 사골 동이나 접형동 등에서도 발생한다. 일반적인 비용과 조직학적인 차이는 없는 것으로 알려져 있다. 후비공비용의 정확한 발생부위를 확인하고 주위의 정상 점막 일부를 함께 제거하는 것이 재발 방지에 중요하다. 